\title{
Franceses y alemanes tras la etiología de la tuberculosis
}

\author{
WALTER LEDERMANN D.
}

\section{French and Germans after the etiology of Tuberculosis}

Los inicios de la bacteriología se caracterizaron, entre otras cosas, por la rivalidad entre franceses y alemanes, encabezados por Pasteur y Koch, respectivamente. En el campo del cólera, así como en el de la difteria, el triunfo perteneció a los germanos, siendo la participación francesa tan minimizada, en aquélla época y en ésta, que la atribución de las cuotas de gloria ha sido eminentemente injusta, como ocurrió entre Behring y Roux a raíz del descubrimiento de la antitoxina diftérica. Si en esta ocasión la cuota del francés fue muy pequeña, en el caso de la tuberculosis toda fue para Koch y nada para el galo Villemin, quien sufrió por ello honda frustración. La historia, cruel y burlona, no sólo ha olvidado a Villemin: también a su frustración.

Se le ha criticado a Koch ignorar los trabajos de quienes le precedieron en su célebre hallazgo, en especial si éstos eran franceses. Sin embargo, su inmortal comunicación sobre el descubrimiento del bacilo comienza citando a Villemin. Si Koch fue justo mencionando el aporte de su rival, seamos justos recordando a un investigador que, a su vez, precedió al francés concibiendo la tuberculosis como enfermedad infecciosa: el alemán Buhl. Tras un exhaustivo estudio anátomo-patológico de la forma miliar, Buhl concluyó en 1857 que esta enfermedad era de carácter infeccioso, causada por la entrada a la sangre de un "veneno" especial, que llamó la materia tuberculosa... Pero -y la lista parece infinitamucho antes, en 1720, conociendo seguramente los trabajos de van Leewenhoek, Benjamín Merton postuló en A new theory of comsumption que la tuberculosis pudiera ser causada por "diminutas criaturas vivientes". Más tarde y siempre en el mismo siglo, en 1784, el romano Natalio Saliceto enunció elegantemente la trasmisión aérea de este mal, utilizando una frase de Rousseau: "Los hombres se envenenan mutuamente al aglomerarse", afirmación que en las congestionadas ciudades del mundo contemporáneo mantiene su trágica validez. Y, por último, recordemos que Bretonneau de Tours, tan familiar a nosotros por sus descripciones sobre la difteria a principios del siglo diecinueve, también jugó su as en esta partida, con una afirmación premonitoria: "Un germen especial, propio de cada contagio, da nacimiento a cada enfermedad infecciosa".

Jean Antoine Villemin (1827-1892), un cirujano militar, hizo noticia en los años sesenta con una serie de papers revolucionarios, amén de un voluminoso texto sobre el tema: Etudes sur la tuberculose (1868).
El 4 de diciembre de 1865, presentó en la Academia de Ciencias de París su primer trabajo, detallando la inoculación de nueve conejos con material tuberculoso humano, todos los cuales desarrollaron lesiones tuberculosas en los próximos meses, en tanto que seis controles no inoculados, que compartían las mismas jaulas, no enfermaron. Otros tres conejos, inyectados uno con material colérico, otro con pus flegmonoso y el tercero con ántrax, tampoco enfermaron de tuberculosis. Su conclusión fue que era ésta "una infección específica y su causa un agente inoculable". En sucesivos trabajos encontró que el material de la enfermedad bovina era más patógeno que el de la humana; que había animales muy sensibles, como el cobayo, y otros más bien refractarios a la variedad humana, como el perro, la oveja, la cabra y algunos pájaros. Por último, demostró que el principio infectante no estaba en la sangre, sino en el esputo, pudiendo adquirirse por inhalación.

Por esa misma época, William Budd coincidió en que la tuberculosis era una enfermedad específica, como la tifoidea o la sífilis, expresando que la "materia tuberculosa" era la responsable del contagio persona a persona, pudiendo ser destruida "a la salida del cuerpo, con medios químicos apropiados", lo cual, sumado a futuras buenas condiciones sanitarias, pudiera llevar a la erradicación del temible mal. En la historia de los descubrimientos bacteriológicos, Budd parece ser el hombre destinado a llegar siempre segundo a corta distancia del ganador: en el caso del cólera, dos meses detrás de Snow, al proclamar la trasmisión acuática por peculiar microscopic object; y en éste, dos años detrás de Villemin con la idea del contagio por inoculación del material tuberculoso.

También perdieron por un pelo Rivolta y Perroncito, que publicaron en 1868 sus exitosas inoculaciones de material bovino en conejos y cobayos, demostrando la identidad histológica de los tubérculos generados en todos estos animales. Igualmente llegó tarde Klebs, al considerar el esputo como vector del "virus" tuberculoso, pero casi superó en cinco años a Koch en el descubrimiento del bacilo: lo tuvo en sus manos y no fue capaz de identificarlo. En efecto, estuvo a punto de cultivarlo en albúmina de huevo, medio de cultivo que mucho después Dorset publicaría como original, haciendo varios traspasos de la "materia tuberculosa" antes de las inoculaciones. Al hacer tinciones de estos 
traspasos, encontró un bacilo muy móvil, que denominó Monas tuberculosum. No sabemos cada cuántos días hacía sus traspasos, pero lo más probable es que sus tiempos fueran muy cortos para permitir el lento desarrollo del verdadero agente causal y así, al fracasar en su cultivo, sólo encontró un contaminante incapaz de reproducir la enfermedad. En sus traspasos de la "materia tuberculosa", sólo iba diluyendo, por diseminación, el valioso inóculo...

Todos estos brillantes investigadores, incluyendo a Villemin, serían postergados por la gloria de Koch, confirmando una sentencia de Dubos: "En la ciencia, la reputación va para el hombre que convence al mundo y no para aquél que tiene la idea en primer término".

Los trabajos de Villemin crearon gran controversia, al fracasar otros autores en sus inoculaciones, hasta que en 1878 un hermoso experimento de Chonheim y Salomonsen dió la razón a Villemin, al inocular animales en la cámara anterior del ojo con material tuberculoso "puro", causándole lesiones tuberculosas en el iris, en tanto que, si el material era "impuro", las lesiones de conejos y cobayos dejaban de ser categóricas.

Después que Bretonneau, en su nativa Tours, expresara su pensamiento sobre la etiología particular de cada enfermedad infecciosa, Jakob Henle había publicado en 1840 su obra capital Von den Miasmen und von den miasmatischcontagiösen Krankheiten, postulando el origen animado de las enfermedades infecciosas y estableciendo algunas bases para identificar a los organismos responsables. Los precedentes estaban, las técnicas mejoraban, las ideas estaban lanzadas y el descubrimiento era inminente. En las palabras de Koch: "bastó sacudir el árbol para que cayeran los frutos maduros".

El 24 de marzo de 1882, tuvo lugar en Berlín la histórica reunión de la Sociedad de Fisiología en que Robert Koch dio a conocer su descubrimiento del bacilo tuberculoso. Según Paul Ehrlich fue "el acontecimiento científico más majestuoso en el que yo haya participado jamás". El público, de acuerdo a un texto de Rapaport y Wright, acogió su conclusión con un silencio total; su opositor, Rudolf Virchow, que tan duramente había atacado la idea de la especificidad de la tuberculosis, abandonó el recinto sin intentar una réplica. El discurso de Koch, publicado el 10 de abril en la página 21 del Berliner Klinischen Wochenschrift, comienza así: "El descubrimiento realizado por Villemin de que la tuberculosis es transmisible a los animales, tuvo, como es sabido, gran número de confirmaciones, aunque también evidentes objeciones bien fundamentadas, de modo pues, que hasta hace pocos años subsistía la duda de si la tuberculosis era o no una enfermedad infecciosa. No obstante, las inoculaciones practicadas desde entonces, primero por Cohnheim y Salomonsen, y por Baumgarten después, en la cámara anterior del ojo, y luego los experimentos inhalatorios de Tappeiner y otros, establecieron, sin lugar a dudas, la transmisibilidad de la tuberculosis, debiéndosele reservar en el futuro un lugar entre las enfermedades infecciosas".
La comunicación completa de Koch es bien extensa, de acuerdo a los cánones modernos, y uno no se explica cómo pudo caber en una sola página del Berliner: en el librito de bolsillo de la Editorial Universitaria de Buenos Aires, donde la hemos leído, ocupa treinta y siete. El autor atribuye su éxito al empleo de una adecuada tinción, en cuya descripción se explaya, y saltándonos la cual llegamos, casi con la misma emoción que sintieran los asistentes a la célebre reunión, al párrafo en que nos presenta por primera vez al mortal enemigo de la raza humana: "Poseen (las bacterias) una morfología semejante a la de un bastoncito, por lo que corresponden al grupo de los bacilos. Son muy delgadas y tienen una longitud igual a la mitad o a un cuarto del diámetro de un glóbulo rojo; a veces pueden alcanzar longitudes mayores, hasta la del diámetro de este último. En lo que respecta a la forma y tamaño, tienen una semejanza sorprendente con los bacilos de la lepra. No obstante, se diferencian de ellos, en última instancia, porque aparecen un poco más esbeltos y tienen sus extremos afilados..."

Toda la publicación, que constituye uno de los más hermosos "clásicos" de la literatura microbiológica, está repleta de pasajes memorables, como aquél en que enumera, con sobriedad espartana, sus famosos postulados, o cualesquiera de los que relatan sus trece experimentos de inoculaciones experimentales: "Dos gatos adultos vigorosos... A una perra de unos cuantos años..." Las conclusiones pueden resumirse en dos de estos pasajes:

$1^{\text {o }}$ "Reunidos todos estos hechos, justifican el veredicto de que los bacilos que se encuentran en los materiales tuberculosos no son simples cómplices del proceso, sino que constituyen la causa del mismo, y que en estos bacilos tenemos ante nosotros al verdadero virus de la tuberculosis".

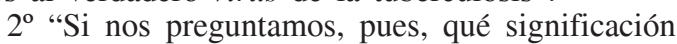
ulterior proporcionan los resultados obtenidos en la investigación, podemos considerarlos, ante todo, como un adelanto para la ciencia, pues se logró, por primera vez, la comprobación completa de la naturaleza parasitaria de una enfermedad infecciosa humana y, en realidad, de la más importante de todas".

Finalmente, expresa su esperanza de que su descubrimiento pueda contribuir a la elaboración de medidas efectivas para el control de la enfermedad, atacando al agente causal o evitando su trasmisión, lo cual resume en su postrera frase: "Cuando el convencimiento de que la tuberculosis es una auténtica enfermedad infecciosa se haya abierto camino entre los médicos, entonces los problemas de la lucha eficaz contra ella provocarán, seguramente, una discusión que se desarrollará de por sî”.

Virchow, mudo, se levantó y se fue. Como dice el poema de Cervantes:

$Y$ luego, incontinente.

caló el chapeo, requirió la espada,

miró de soslayo, fuese, y no hubo nada.

La verdad es que no sólo Virchow guardó silencio: todos quedaron mudos, nadie hizo una pregunta, nadie se atrevió a oponer una objeción, y el profesor Dubois Reymond se vio obligado a levan- 
tar la sesión. Toda la investigación de Koch demoró seis meses; su exposición, casi dos horas; su proyección, hasta hoy.

En realidad, como modestamente lo reconoció, Koch sólo partió de los trabajos de Cohnheim y de Villemin, quienes ya habían postulado la naturaleza infecciosa de la enfermedad, llegando al éxito por su rigor técnico. ¿Por qué la gloria inmensa que obtuvo? (¡En Japón se le construyó un templo!). Sin duda por la tremenda significación que la tuberculosis había tenido siempre en la salud pública. Ello hizo que su gloria persistiera, a pesar que, como dice Waksman, el mismo Koch echó a perder su trabajo considerablemente, al anunciar en 1890 que había descubierto una sustancia que protegía contra la enfermedad: "la linfa de Koch, noticia que causó júbilo... y luego rabia. La substancia, cuya composición el investigador mantuvo en secreto, en apariencia por razones políticas (imposición del gobierno alemán), era la tuberculina, a la postre una excelente herramienta diagnóstica, pero desprovista de propiedades curativas. La crítica fue doble al hacerse evidente el fracaso terapéutico: por su incorrecto comportamiento, al intentar conservar en secreto la composición de la sustancia, y por su falta de criterio científico, al recomendarla como terapia."

¿Habrá representado ello un consuelo para Villemin? El desengañado sabio escribe a Pasteur, en 1887: "No abrigo la esperanza de obtener un lugar a su lado -verá usted que soy menos modesto de lo que aparento- pero se me ha discutido tanto, he sido atacado tan a menudo, que siento cierta pesadumbre al pensar que la más importante academia científica aún concede una suerte de tolerancia a mis antiguos enemigos". Y, más adelante: "El bacilo de Koch, del cual se enorgullecen tanto los alemanes, obscureció el recuerdo de los resultados ya logrados por los científicos franceses. Koch entrará en la Academie des Sciences, que le abrirá sus puertas de par en par, del modo triunfal con que ha conquistado todos los honores en su país".

Antes y después de Villemin y Koch hubo controversias, algunas muy ácidas, en el campo de la tuberculosis. Quizás nos refiramos a ellas en otra ocasión.

\section{Bibliografía}

1.- Griffith S et al. Bacillus tuberculosus. En: A system of bacteriology in relation to medicine. His Majesty's Stationery Office, London 1930; V: 151-6.

2.- Waksman S. La conquista de la tuberculosis. Editorial Hobbs, Buenos Aires 1968; 87-116.

3.- Laín Entralgo P. Historia de la medicina. Salvat, Barcelona 1978; 464-518.

4.- Koch R. La etiología de la tuberculosis y otros trabajos. Editorial Universitaria, Buenos Aires 1965; 4986. 